\title{
The Role of Surface Charge in Ionic Germination of Clostridium perfringens Spores
}

\author{
By YOSHIAKI ANDO* AND TOSHIBUMI TSUZUK I \\ Hokkaido Institute of Public Health, Sapporo 060, Japan
}

(Received 28 June 1983; revised 3 October 1983)

The surface charge against pH behaviour of spores of Clostridium perfringens type A was determined using a colloid titration method in the $\mathrm{pH}$ range 4-9. The native spores as well as various ionic forms of the spores loaded with divalent cations were found to be negatively charged. A positive colloid, MGCh, inhibited the ionic germination of the spores and this inhibition was highly dependent on $\mathrm{pH}$. However, another positive colloid, $\mathrm{GCh}$, did not inhibit the germination. Chemical modification of carboxyl groups on the spore surface by use of a water-soluble carbodiimide with two nucleophiles, glycine ethyl ester and taurine, caused spores not only to have little or no colloidal charge but also to lose the ability to germinate. The modification of carboxyl groups in the spore coat protein also resulted in elimination of, or marked reduction in its negative charge. These results suggest that carboxyl groups in the spore coat protein are the major negatively charged species on the spore surface. The role of surface charge in the ionic germination of the spores is discussed.

\section{INTRODUCTION}

Since the early work of Douglas (1955), which showed that bacterial spores were negatively charged, a few reports concerning microelectrophoretic mobility of spores have appeared in which it has been suggested that carboxyl groups are responsible for the negatively charged species on the spore surfaces (Tochikubo et al., 1975; Gore et al., 1978; Wyatt et al., 1982). However, little is known about the function of the charged species present in the spore surface, in particular the possible involvement of the charged carboxyl groups in germination. Nishihara et al. (1981), using the colloid titration method (Watanabe \& Takesue, 1976), measured the surface charge of Bacillus megaterium QM B1551 spores and concluded that there existed two types of the negatively charged species on the spore surface, one being strong acidic groups such as phosphates and the other being weak acidic groups such as carboxylates. They also suggested that the phosphate residues might block the action of ionic germination and the carboxylate residues might be involved in the later stage of germination. However, their data gave no evidence that phosphate or carboxylate residues present in the spore coat are attributable to the major sites of the negatively charged species on the spore surface.

In this paper, we attempt to locate the sites of carboxyl charges on the spore surface of Clostridium perfringens by comparing the colloid titration values of native spores with those in which the carboxyl charges have been chemically modified or eliminated. We also describe an important role of the charged carboxyl groups arising from the spore coat protein in ionic germination of the spores.

\section{METHODS}

Organism and preparation of spores. Clostridium perfringens type A strain, National Collection of Type Cultures 8238 (Hobbs' serotype 2) was used. The cultures were maintained in cooked meat medium (Difco). Spores were

Abbreviations: GCh, glycol chitosan; MGCh, methylglycol chitosan 
prepared by the method of Duncan \& Strong (1968) and were freed of vegetative cells by mild ultra-sonication followed by extensive washings with deionized water. They were stored in water at $2^{\circ} \mathrm{C}$.

Preparation of ionic forms of spores. Aqueous suspensions of the spores were converted to the hydrogen form $(\mathrm{H}-$ spores) by titration to $\mathrm{pH} 4$ with $0.01 \mathrm{M}-\mathrm{HNO}_{3}$ (Alderton \& Snell, 1963). Spores loaded with $\mathrm{Ca}^{2+}, \mathrm{Mg}^{2+}, \mathrm{Sr}^{2+}$, and $\mathrm{Ba}^{2+}$ were prepared by titrating aqueous suspensions of $\mathrm{H}$-spores to $\mathrm{pH} 9$ with the hydroxide of these metals (Levinson \& Hyatt, 1969).

Germination of spores. Heat-activated $\left(80^{\circ} \mathrm{C}\right.$ for $\left.10 \mathrm{~min}\right)$ spores were germinated in a $\mathrm{KCl}$ medium consisting of $50 \mathrm{mM}-\mathrm{KCl}$ and $50 \mathrm{~mm}$-potassium phosphate buffer $\left(\mathrm{pH} \mathrm{7.0)}\right.$ ) at $40^{\circ} \mathrm{C}$. The optical density changes were measured using a Klett-Summerson photoelectric colorimeter (filter no. 56). Germination was also confirmed by phasecontrast microscopy.

Colloid titration. The slightly modified method of Watanabe \& Takesue (1976) was used. Instead of protamine sulphate, GCh and MGCh (Wako Pure Chemical Corp.) were used as positive colloids, since Nishihara $e t$ al. (1981) reported that titration values were estimated to be higher with protamine sulphate than with MGCh. An excess amount of the colloid $(0.005 \mathrm{M}, 5 \mathrm{ml})$ was added to an appropriate concentration of spores $(20-30 \mathrm{mg}$ per $2 \mathrm{ml}$ ) and the mixture was adjusted to the required $\mathrm{pH}$ with $0.05 \mathrm{M}-\mathrm{HCl}$ or $0.05 \mathrm{M}-\mathrm{NaOH}$. After incubation at room temperature for $20 \mathrm{~min}$, the uncombined colloid was back-titrated with $0.0025 \mathrm{M}$-potassium polyvinyl sulphate (Wako Pure Chemical Corp.) using toluidine blue as the indicator. A sharp end-point with MGCh was obtained by removing the spores by centrifuging the titration mixture and adjusting the $\mathrm{pH}$ of the supernatant to 2.5 with $0.05 \mathrm{M}-\mathrm{HCl}$ before titration, according to the method of Nishihara et al. (1981).

Preparation of spore integuments and coat protein. Spores were disrupted by shaking with glass beads in a Braun cell homogenizer as described previously (Ando, 1979). After removal of the glass beads, the disrupted spore suspension was centrifuged at $12000 \mathrm{~g}$ for $20 \mathrm{~min}$. The pellet was washed several times with deionized water at $4{ }^{\circ} \mathrm{C}$. Spore coat protein was extracted from the spore integuments as follows. Spore integuments $\left(6 \cdot 2 \mathrm{mg} \mathrm{ml}^{-1}\right)$ were treated with lysozyme $\left(100 \mu \mathrm{g} \mathrm{ml}^{-1}\right)$ in $0.01 \mathrm{M}$-Tris/ $\mathrm{HCl}$ buffer, $\mathrm{pH} \mathrm{7.8}$, at $30^{\circ} \mathrm{C}$ for $60 \mathrm{~min}$ before washing several times with deionized water. After lysozyme treatment, the coat fraction $\left(5 \mathrm{mg} \mathrm{ml}^{-1}\right)$ was suspended in a freshly prepared solution of $50 \mathrm{~mm}$-DTT. The $\mathrm{pH}$ was adjusted to 10.5 with $0.1 \mathrm{M}-\mathrm{NaOH}$. The suspension was incubated at $40^{\circ} \mathrm{C}$ for $60 \mathrm{~min}$, and centrifuged. The resulting supernatant containing coat protein was dialysed against deionized water and lyophilized.

Chemical modification of carboxyl groups. Two nucleophiles of different electrical charge were coupled with carboxyl groups by the carbodiimide reaction (Hoare \& Koshland, 1967). One was glycine ethyl ester which neutralized the carboxyl charges and the other was taurine which, after coupling, remained negatively charged. Spores $\left(10 \mathrm{mg} \mathrm{ml}^{-1}\right)$ were suspended in $10 \mathrm{ml}$ aqueous $0.2 \mathrm{M}$-1-ethyl-3-(3-dimethylaminopropyl)carbodiimide hydrochloride (Wako Pure Chemical Corp.) with $0.5 \mathrm{M}$-nucleophile. The mixture was continuously stirred for $6 \mathrm{~h}$ at $25^{\circ} \mathrm{C}$. The $\mathrm{pH}$ was adjusted to 4.75 and this value was maintained by addition of $0.05 \mathrm{M}-\mathrm{NaOH}$. The treated spores were washed several times with deionized water by centrifugation. Spore coat protein was treated essentially as described above.

To detect modified carboxyl groups, $3 \mathrm{mg}$ of each sample was hydrolysed in $6 \mathrm{M}-\mathrm{HCl}$ at $110^{\circ} \mathrm{C}$ for $20 \mathrm{~h}$ in a sealed Pyrex-glass tube, and the amounts of glycine and taurine, as compared to untreated control, were determined by a Hitachi model 835 Amino Acid Analyser.

\section{RESULTS}

\section{Surface charge of spores against $\mathrm{pH}$ behaviour}

Figure 1 shows the $\mathrm{pH}$ dependence of the colloidal charge of $\mathrm{Cl}$. perfringens spores titrated with MGCh or GCh. The colloidal charge was almost zero at pH 4 but increased steadily toward negative values as the $\mathrm{pH}$ was raised from 4 to 9 when the spores were titrated with MGCh. Little or no charge was observed between these $\mathrm{pH}$ values when the spores were titrated with GCh. This implies that weak acidic groups such as carboxyl groups are the only charged species on the spore surface because $\mathrm{MGCh}$ reacts with all negatively charged groups including carboxyl groups, while GCh dissociates at $\mathrm{pH}<6.5$ and reacts only with strong acidic groups dissociable even at low pH (Nishihara et al., 1981).

\section{Surface charge and germination ability of various ionic forms of spores}

Table 1 shows variations in colloidal charge at three different $\mathrm{pHs}$ for various ionic forms of the spores, along with the ability of these spores to germinate in the $\mathrm{KCl}$ medium. The colloidal charges of all these ionic forms of the spores were zero at $\mathrm{pH} 4$ but increased to more negative values with increasing $\mathrm{pH}$ values, as in the case of native spores. However, the colloidal titration values of these ionic forms of the spores were about half those of native or $\mathrm{H}$-spores. The 


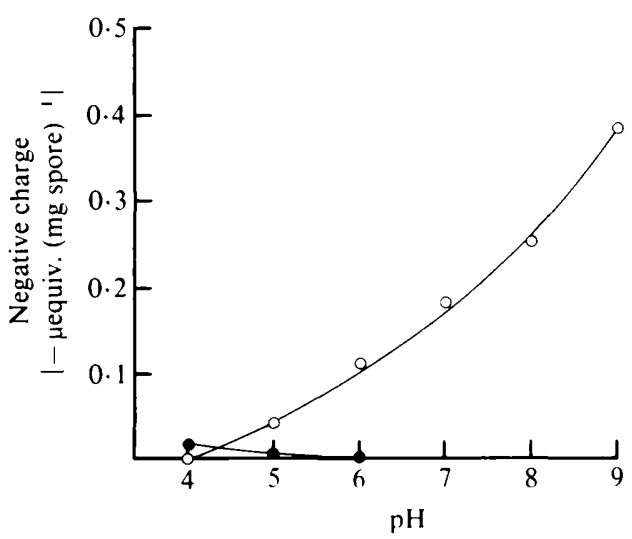

Fig. 1

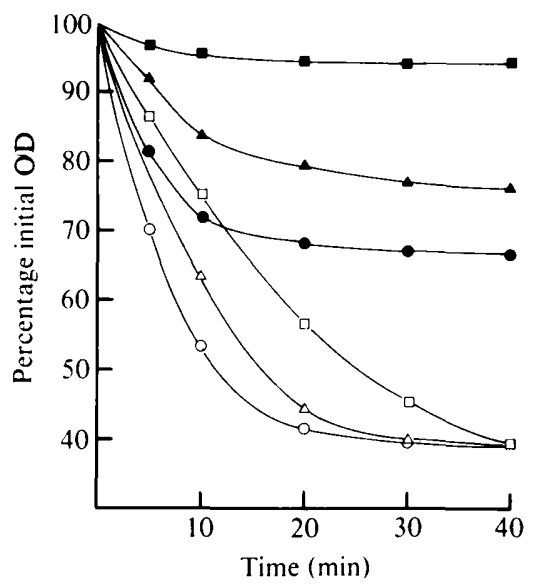

Fig. 2

Fig. 1. pH-colloidal charge curve of $\mathrm{Cl}$. perfringens spores. Spores were titrated with MGCh $(\mathrm{O})$ or GCh (O).

Fig. 2. Effect of $\mathrm{pH}$ on the inhibition of the ionic germination of $\mathrm{Cl}$. perfringens spores by MGCh. The heat-activated spores were preincubated in $50 \mathrm{~mm}$-Tris/ $\mathrm{HCl}$ buffer alone (open symbols), or containing MGCh (closed symbols) at varying $\mathrm{pHs}$ for $20 \mathrm{~min}$ at $40^{\circ} \mathrm{C}$, and then $\mathrm{KCl}$ was added to make its concentration $50 \mathrm{~mm}$ at the zero time. $\mathrm{O}, \bigcirc, \mathrm{pH} 7.5 ; \triangle, \Delta, \mathrm{pH} \mathrm{8.0; \square}, \boldsymbol{\square}, \mathrm{pH} \mathrm{8.5}$.

Table 1. Colloidal charge and germination ability of various ionic forms of $\mathrm{Cl}$. perfringens spores

Values for colloidal charge are given as $\mu$ equiv. (mg spore dry wt) ${ }^{-1}$ and for germination ability as percentage fall in OD after $60 \mathrm{~min}$.

\begin{tabular}{lcccc} 
Ionic form & \multicolumn{2}{c}{ Colloidal charge } & Germination \\
\cline { 2 - 4 } & $\mathrm{pH} 4$ & $\mathrm{pH} 7$ & $\mathrm{pH} \mathrm{9}$ & $\begin{array}{c}\text { ability } \\
\text { Native }\end{array}$ \\
$\mathrm{H}^{+}$ & 0 & -0.18 & -0.38 & 64 \\
$\mathrm{Ca}^{2+}$ & 0 & -0.21 & -0.39 & 15 \\
$\mathrm{Sr}^{2+}$ & 0 & -0.13 & -0.20 & 56 \\
$\mathrm{Ba}^{2+}$ & 0 & -0.12 & -0.23 & 62 \\
$\mathrm{Mg}^{2+}$ & 0 & -0.11 & -0.21 & 55 \\
& 0 & -0.13 & -0.23 & 64
\end{tabular}

germination ability of these spores except $\mathrm{H}$-spores was almost the same. The rate of germination of $\mathrm{H}$-spores was very slow in the $\mathrm{KCl}$ medium, but they finally germinated to the same extent that native spores normally attained within $60 \mathrm{~min}$.

\section{Effect of MGCh on germination}

Since it was possible that MGCh reacted with some carboxyl groups on the spore surface to neutralize their negative charge, the effect of MGCh on the ionic germination of the spores was studied. Heat-activated spores were preincubated at $40{ }^{\circ} \mathrm{C}$ with $\mathrm{MGCh}$ [10 $\mu$ equiv. (mg spore $)^{-1}$ ] in $50 \mathrm{~mm}$-Tris/ $\mathrm{HCl}$ buffers of varying $\mathrm{pH}$ values for $20 \mathrm{~min}$, and then $\mathrm{KCl}$ was added to the mixture to give a final concentration of $50 \mathrm{mM}$. In the absence of $\mathrm{MGCh}$, changes in $\mathrm{pH}$ values between 7.5 and 8.5 exerted little measurable effect on the ionic germination of the spores (Fig. 2). However, germination was strongly inhibited in the presence of MGCh and this inhibition was highly pH-dependent (Fig. 2). Although the inhibitory action of MGCh was most effective at $\mathrm{pH} 8 \cdot 5$, there was a complete reversal of the inhibition when the inhibitor was removed by washing with water. When $\mathrm{MGCh}$ was replaced by $\mathrm{GCh}$, no inhibition of germination was observed over the $\mathrm{pH}$ range 6.5 to 7.5 . 
Table 2. Amino acid composition of integuments from chemically modified spores

Values are given as molar percentages.

Amino acid

Taurine

Aspartic acid

Threonine

Serine

Glutamic acid

Proline

Glycine

Alanine

Valine

Methionine

Isoleucine

Diaminopimelic acid

Leucine

Tyrosine

Phenylalanine

Lysine

Histidine

Arginine Glycine-ethyl-ester-
modified spores

$$
0.0
$$

$10 \cdot 0$

$4 \cdot 0$

$5 \cdot 4$

$13 \cdot 1$

$3 \cdot 8$

$16 \cdot 7$

$9 \cdot 7$

$4 \cdot 4$

$1 \cdot 4$

$4 \cdot 3$

$2 \cdot 5$

6.0

$2 \cdot 8$

$3 \cdot 1$

$7 \cdot 2$

$1 \cdot 8$

$4 \cdot 2$
Taurine-

modified spores

6.8

$10 \cdot 4$

$4 \cdot 2$

$6 \cdot 3$

$13 \cdot 3$

$4 \cdot 4$

7.6

$10 \cdot 2$

$3 \cdot 8$

$1 \cdot 3$

$3 \cdot 9$

$3 \cdot 1$

$5 \cdot 9$

$3 \cdot 2$

3.0

6.7

1.8

$4 \cdot 3$

Table 3. A comparison in colloidal charge and germination ability between modified and unmodified spores

Values for colloidal charge are the same as those in the legend to Table 1 and those for germination ability are given as percentages of phase-dark spores after $60 \mathrm{~min}$. The following media were used for germination at the indicated pHs. $50 \mathrm{mM}-\mathrm{KCl}+50 \mathrm{~mm}$-sodium acetate buffer $(\mathrm{pH} 4) ; 50 \mathrm{mM}-\mathrm{KCl}+$ $50 \mathrm{~mm}$-sodium phosphate buffer $(\mathrm{pH} 7) ; 50 \mathrm{mM}-\mathrm{KCl}+50 \mathrm{~mm}-\mathrm{Tris} / \mathrm{HCl}$ buffer $(\mathrm{pH} 9)$.

Modified spores

Glycine-ethyl-ester-modified spores Taurine modified spores Unmodified spores

\begin{tabular}{|c|c|c|c|c|c|}
\hline \multicolumn{3}{|c|}{ Colloidal charge } & \multicolumn{3}{|c|}{ Germination ability } \\
\hline $\mathrm{pH} 4$ & $\mathrm{pH} 7$ & $\mathrm{pH} 9$ & $\mathrm{pH} 4$ & $\mathrm{pH} 7$ & pH 9 \\
\hline $\mathbf{0}$ & 0 & 0 & 0 & 0 & 0 \\
\hline 0 & -0.03 & -0.06 & 0 & 0 & 0 \\
\hline 0 & -0.18 & -0.38 & 6 & 97 & 81 \\
\hline
\end{tabular}

\section{Modification of carboxyl groups on the spore surface}

The native spores were treated as described in the text with water-soluble carbodiimide in the presence of either glycine ethyl ester or taurine. Amino acid analyses of the integuments from glycine-ethyl-ester-modified spores (GE-spores) and taurine-modified spores (T-spores) were compared with one another (Table 2). Taurine was detected in large quantities in T-spores but none of it in GE-spores. On the contrary, the glycine content of GE-spores was about twice as much as that of $\mathrm{T}$-spores. These results indicated that approximately equal numbers of carboxyl groups on the surface were affected by the modification with glycine ethyl ester or taurine. The modification of carboxyl groups yielded spores with little or no colloidal charges at the three $\mathrm{pHs}$, as compared to unmodified spores (Table 3 ). T-spores had slightly negative values at $\mathrm{pH} 7$ and 9, while GE-spores had a zero colloid titration value irrespective of $\mathrm{pH}$. Furthermore, the modification of carboxyl groups resulted in complete loss of ability to germinate even at $\mathrm{pH} 7$, where optimum germination of unmodified spores was observed (Table 3).

\section{Modification of carboxyl groups in the spore coat protein}

To determine if most of the carboxyl groups on the spore surface are located in the spore coat,

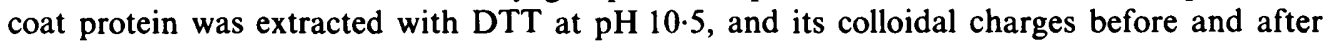
modification of its carboxyl groups were compared. Since it was impossible to extract coat 
Table 4. Amino acid composition of modified and unmodified spore coat proteins

\begin{tabular}{|c|c|c|c|}
\hline \multicolumn{4}{|c|}{ Values are given as molar percentages. } \\
\hline Amino acid & $\begin{array}{l}\text { Glycine-ethyl- } \\
\text { ester-modified } \\
\text { coat protein }\end{array}$ & $\begin{array}{l}\text { Taurine- } \\
\text { modified } \\
\text { coat protein }\end{array}$ & $\begin{array}{l}\text { Unmodified } \\
\text { coat protein }\end{array}$ \\
\hline Taurine & $0 \cdot 0$ & $8 \cdot 1$ & 0.0 \\
\hline Aspartic acid & 11.8 & $12 \cdot 4$ & $13 \cdot 5$ \\
\hline Threonine & $3 \cdot 3$ & $3 \cdot 5$ & 3.7 \\
\hline Serine & $4 \cdot 3$ & $4 \cdot 2$ & 4.6 \\
\hline Glutamic acid & 11.9 & $12 \cdot 3$ & 13.5 \\
\hline Proline & $4 \cdot 6$ & 3.8 & 4.1 \\
\hline Glycine & $18 \cdot 7$ & $9 \cdot 6$ & $10 \cdot 3$ \\
\hline Alanine & $4 \cdot 0$ & $4 \cdot 1$ & $4 \cdot 4$ \\
\hline Valine & $4 \cdot 6$ & $4 \cdot 6$ & 4.9 \\
\hline Methionine & 1.5 & 1.5 & 1.7 \\
\hline Isoleucine & $4 \cdot 8$ & 4.8 & $5 \cdot 1$ \\
\hline Leucine & 7.5 & 7.6 & $8 \cdot 2$ \\
\hline Tyrosine & $3 \cdot 7$ & 3.7 & 4.6 \\
\hline Phenylalanine & $3 \cdot 7$ & $3 \cdot 7$ & $4 \cdot 0$ \\
\hline Lysine & $8 \cdot 2$ & $8 \cdot 5$ & $9 \cdot 2$ \\
\hline Histidine & $2 \cdot 4$ & $2 \cdot 4$ & $2 \cdot 6$ \\
\hline Arginine & $5 \cdot 1$ & $5 \cdot 2$ & 5.5 \\
\hline
\end{tabular}

Table 5. Colloidal charge of modified and unmodified spore coat proteins

Values are given as $\mu$ equiv. (mg dry wt protein) ${ }^{-1}$. The buffers used are given in Table 3.

\begin{tabular}{|c|c|c|c|}
\hline \multirow[b]{2}{*}{ Coat protein } & \multicolumn{3}{|c|}{ Colloidal charge } \\
\hline & pH 4 & $\mathrm{pH} 7$ & pH 9 \\
\hline $\begin{array}{l}\text { Glycine-ethyl-ester- } \\
\text { modified coat protein }\end{array}$ & +0.02 & +0.02 & +0.05 \\
\hline $\begin{array}{l}\text { Taurine-modified } \\
\text { coat protein }\end{array}$ & 0 & -0.08 & -0.33 \\
\hline $\begin{array}{l}\text { Unmodified } \\
\text { coat protein }\end{array}$ & 0 & -0.54 & $-0 \cdot 82$ \\
\hline
\end{tabular}

protein from the integuments of the chemically modified spores due to difficulties in solubilizing it into the alkaline DTT, spore coat protein extracted from native spores was treated for the modification of carboxyl groups. Table 4 shows a comparison of amino acid composition of the coat protein before and after modification of carboxyl groups with either glycine ethyl ester or taurine. These results showed that the coat protein was characterized by a relatively high content of acidic amino acids (aspartic and glutamic). The numbers of taurine and glycine residues incorporated were almost the same and corresponded to more than one half of that of either aspartic or glutamic residues. The colloid titration of native coat protein showed that the net charge was zero at $\mathrm{pH} 4$ but increased toward more negative values with increasing $\mathrm{pH}$ values (Table 5). However, the modification of carboxyl groups in the coat protein resulted in the elimination of, or marked reduction in its negative charge. Glycine-ethyl-ester-modified coat protein had slightly positive charges irrespective of $\mathrm{pH}$, while taurine-modified coat protein had much less negative charges dependent on $\mathrm{pH}$ than those of unmodified coat protein.

\section{DISCUSSION}

The surface charge of $\mathrm{Cl}$. perfringens spores was found to be negative at $\mathrm{pH}>4$ from the $\mathrm{pH}$ colloidal charge curve (Fig. 1), suggesting that the only ionizable species on the spore surface are weakly acidic groups such as carboxyl groups. These results are in agreement with those from 
microelectrophoretic studies on some Bacillus spores. However, a difference in surface charges of spores in terms of the colloid titration was observed between $\mathrm{Cl}$. perfringens and Bacillus megaterium. The negatively charged groups of the latter spores comprised mainly phosphates and carboxylates because they were titratable with both GCh and MGCh. Since measurement of colloid titration value provides information only about the surface of a spore as a colloid particle, the difference may be due to some morphological and chemical properties of the spore surfaces, in particular of the outermost layers of the spore coats. The outer coat of B. megaterium spoies was constituted mainly by a resistant fraction containing phosphogalactosamine (Kondo $\&$ Nishihara, 1970), whereas the outer coat of $\mathrm{Cl}$. perfringens spores was composed mainly of DTT-alkali-soluble protein (Labbe et al., 1978). Therefore, colloid titration values of these spores are concerned with the degree of dissociation of these components in the outer coats, which should be influenced by the $\mathrm{pH}$ or ionic strength of the surroundings.

The ionic germination of $\mathrm{Cl}$. perfringens spores was greatly inhibited in the presence of $\mathrm{MGCh}$ and the inhibition was highly dependent on $\mathrm{pH}$, suggesting that MGCh-reactive carboxyl groups on the spore surface may play an important role in the ionic germination of the spores. MGCh might combine reversibly with the carboxyl groups by neutralizing their negative charge, thus leading to the inhibition of certain events early in germination. The inhibitory action of MGCh was complete as determined by the microscopic observation. This was in contrast to the case of $\boldsymbol{B}$. megaterium spores, in which germination was partially inhibited to yield semi-refractile spores. Nishihara et al. (1981) suggested that the action of MGCh on germination might be the fixation of the coat components by reaction with the carboxyl groups, leading to the prevention of the second stage of the germination. These discrepancies may also be accounted for by the difference in the morphological and chemical properties between the surfaces of these spores.

The presence of carboxyl groups on the spore surface was further evidenced by investigating the effect of water-soluble carbodiimide, a reagent for modifying free carboxyl groups, on the colloidal charge of the spores. Glycine-ethyl-ester-modified spores had zero colloidal charge irrespective of $\mathrm{pH}$, indicating a direct result of the elimination of the negative charge due to the carboxyl groups. In addition, these modified spores could no longer germinate in the $\mathrm{KCl}$ medium. This also means that some negatively charged carboxyl groups are involved in the ionic germination of the spores. The chemical modification of the carboxyl groups in the spore coat protein caused a significant reduction in colloidal charge, suggesting that the negatively charged loci of the spore surface are acidic proteins in the spore coat.

Although a number of studies have been made on the chemical properties of spore coat proteins (Aronson \& Fitz-James, 1976), little is known of their function. Gould et al. (1970) suggested that the bacterial spore coat consisted of the two major proteins, disulphide-rich protein and alkali-soluble protein, both of which were located in the outer coat region of spores, and that alkali-soluble protein was involved in protecting the spores from enzymes but not in determining heat or radiation resistance. Labbe et al. (1978) reported that extraction of the coat protein with alkaline DTT from $\mathrm{Cl}$. perfringens spores rendered the spores sensitive to lysozyme. These findings imply that lysozyme can penetrate the altered spore coat to reach the underlying cortex. In other words, alkali-soluble coat protein plays a role in the reinforcement of the coat as a permeability barrier. In a previous paper (Ando, 1975), we reported that $\mathrm{H}$-spores of $\mathrm{Cl}$. perfringens were sensitive to germination by lysozyme, but not Ca-spores. Although we have not yet studied the chemical properties of the alkali-soluble protein of the organism in detail, the protein was caused to precipitate with $\mathrm{Ca}^{2+}, \mathrm{Mg}^{2+}$ and other divalent cations probably due to the formation of an associated complex ( $Y$. Ando \& $T$. Tsuzuki, unpublished data). If we assume that $\mathrm{H}$ - and $\mathrm{Ca}$-spores comprise spore coat proteins as a dissociative and an associative form, respectively, the permeability of these spores to lysozyme would be explicable by the dissociation and association of the DTT-alkali-soluble protein. However, most of the carboxyl groups in the coat protein of $\mathrm{H}$-spores seemed to have existed in an un-ionized form, because $\mathrm{H}$-spores germinated so poorly in the $\mathrm{KCl}$ medium, as did native spores at $\mathrm{pH} 4$. In fact, $\mathrm{H}$-spores were transformed by incubation with a sodium phosphate buffer from the protonated form to a dissociated one, i.e., Na-spores, which are sensitive to lysozyme (Y. Ando \& T. Tsuzuki, 
unpublished data). Moreover, spores loaded with $\mathrm{Ca}^{2+}$ and other divalent cations still retained their colloidal charges and ability to germinate as well (Table 1). It is, therefore, reasonable to suppose that only a part of the DTT-alkali-soluble protein that is associated with $\mathrm{Ca}^{2+}$ may be responsible for preventing lysozyme from penetrating the spore coat. Nevertheless, the chemical modification of carboxyl groups in the spore coat caused alteration of the alkali-soluble protein to an alkali-insoluble one, thus yielding an altered spore coat having much reduced negative charge and impermeable to lysozyme as well as inorganic germinants (Y. Ando \& T. Tsuzuki, unpublished data).

In view of the fact that bacterial spores behave as cation-exchangers (Alderton \& Snell, 1963), the cation exchange capacity of the spores must be closely associated with the fixed, negatively charged carboxyl groups in the spore coat protein. The distribution of exchangeable cations such as $\mathrm{Ca}^{2+}$ or $\mathrm{Sr}^{2+}$ in the coat or subcoat region has been reported elsewhere (Tsuzuki \& Ando, 1982). The reduced negative colloidal charges of spores loaded with various divalent cations might be the result of binding of the spore coat with divalent cations that can neutralize the negative charge (Table 1). The spore coat has properties very similar to those of a cationexchange resin. It adsorbs more cations than anions from its environment due to the presence of fixed anions according to the Donnan equilibrium. Cation-exchange resin also shows swelling effects which are influenced by ionic strength. In the case of the ionic germination of the spores, coat swelling is considered to occur as soon as spores are suspended in the $\mathrm{KCl}$ medium, and thereafter the adsorbed $\mathrm{K}^{+}$will initiate germination in such a way as has been reported previously (Ando, 1979).

\section{REFERENCES}

Alderton, G. \& Snell, N. (1963). Base exchange and heat resistance in bacterial spores. Biochemical and Biophysical Research Communications 10, 139143.

ANDO, Y. (1975). Effect of lysozyme on ionic forms of spores of Clostridium perfringens type A. Journal of Bacteriology 122, 794-795.

ANDO, Y. (1979). Spore lytic enzyme released from Clostridium perfringens spores during germination. Journal of Bacteriology 140, 59-64.

Aronson, A. I. \& Fitz-James, P. C. (1976). Structure and morphogenesis of the bacterial spore coat. Bacteriological Revien's 40, 360-402

Douglas, H. W. (1955). Electrophoretic studies on bacterial spores. Resting spores of $B$. megaterium and B. subtilis. Transactions of the Faraday Society 51, 146-152.

Duncan, C. L. \& Strong, D. H. (1968). Improved medium for sporulation of Clostridium perfringens. Applied Microbiology 16, 412-416.

Gore, M. S., Sherekar, S. V., Kumta, U. S. \& PhondKe, G. P. (1978). Microelectrophoretic studies on spores of Bacillus licheniformis: influence of spore coat extraction procedures on electrophoretic mobility. Indian Journal of Biochemistry and Biophysics 15, 299-303.

Golld, G. W., Stubbs, J. M. \& King, W. L. (1970). Structure and composition of resistant layers in bacterial spore coats. Journal of General Microbiology 60, 347-355.

Hoare, D. G. \& Koshland, D. E., JR (1967). A method for quantitative modification and estimation of carboxylic acid groups in proteins. Journal of Biological Chemistry 242, 2447-2453.
Kondo, M. \& Nishihara, T. (1970). Studies on the bacterial spore coat. (2) Chemical structures of fractions isolated from the dormant spore coat of Bacillus megaterium. Japanese Journal of Bacteriology 25, 215-221.

Labbe, R. G., Reich, R. R. \& Duncan, C. L. (1978). Alteration in ultrastructure and germination of Clostridium perfringens type A spores following extraction of spore coats. Canadian Journal of Microbiology 24, 1526-1536.

Levinson, H. S. \& HyatT, M. T. (1969). Activation of Bacillus megaterium spore germination. In Spores IV, pp. 262-275. Edited by L. L. Campbell. Bethesda, Md., USA: American Society for Microbiology.

Nishihara, T., Yoshimoto, I. \& Kondo, M. (1981). Studies on the bacterial spore coat. IX. The role of surface charge in germination of Bacillus megaterium spores. Microbiology and Immunology' 25, 763-771.

Tochikubo, K., Kojima, K. \& Hachisuka, Y. (1975). Electrokinetic charge of resting and germinated spores of Bacillus subtilis. In Spores VI, pp. 526-530. Edited by P. Gerhardt., R. N. Costilow \& H. L. Sadoff. Washington, D.C.: American Society for Microbiology.

TsuzUKI, T. \& ANDO, Y. (1982). Location of exchangeable cations within the spore of Clostridium perfringens. Japanese Journal of Bacteriology 37, 875-881.

Watanabe, K. \& Takesue, S. (1976). Colloid titration for determining the surface charge of bacterial spores. Journal of General Microbiology 96, 221-223.

WYATT, J., WaItES, W. M. \& MORRIS, V. J. (1982). Microelectrophoretic studies of coat-defective spores of Bacillus megaterium. Journal of General Microbiology 128, 1661-1666. 